\title{
IV. Of the conditions of life
}

\section{Rev. Patrick Keith F.L.S.}

To cite this article: Rev. Patrick Keith F.L.S. (1831) IV. Of the conditions of life, Philosophical Magazine Series 2, 10:55, 32-40, DOI: 10.1080/14786443108675674

To link to this article: http://dx.doi.org/10.1080/14786443108675674

曲 Published online: 14 Jul 2009.

Submit your article to this journal

Џll Article views: 3

Q View related articles $₫$ 
Elements of the Transit of Mercury.

Apparent time of Berlin.

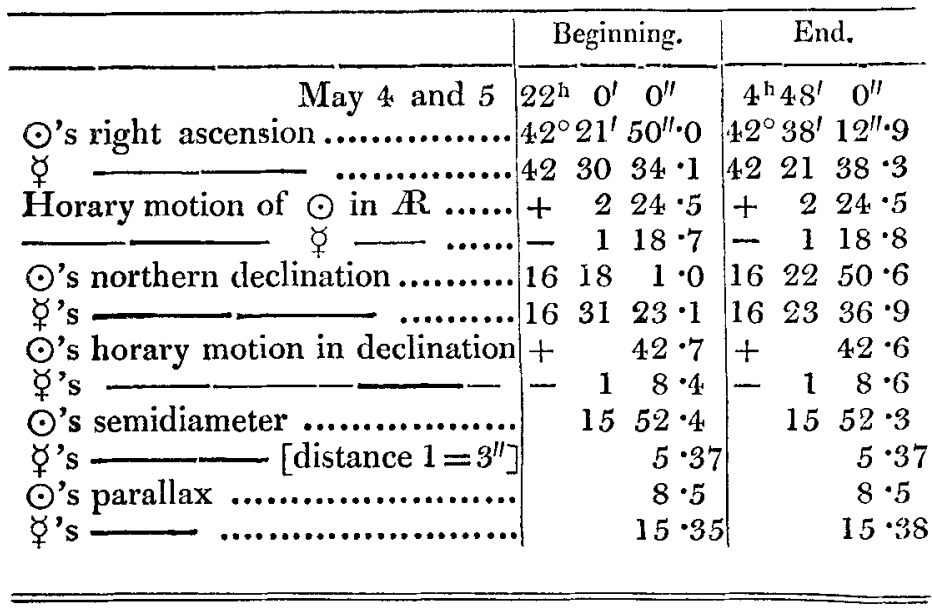

IV. Of the Conditions of Life. By the Rev. Patrick Kerth, F.L.S.*

WHAT is life?-The great variety of definitions by which physiologists have attempted to exhibit an idea of life, shows that it is no easy task to do so correctly. The subtile and untangible character of the subject to be defined is doubiless the grand cause of the difficulty. Bichât, a French physiologist of great celebrity, defined it as follows: "La vie est l'ensemble des fonctions qui resistent à la mort t,"-Life is the totality of the functions that resist death. It is a trait from the pencil of a great master, but it is by much too indefinite to exhibit a distinct view of the subject. Functions seem to be rather the result of life, than to be life itself. But what is the amount of their resistance? for death finally overcomes them; and of what class of bodies are they predicable?Richerand defined it thus: "La vie est une collection de phénomènes qui succedent pendant un temps limité dans les corps organisés $\ddagger$,,- Life is a collection of phænomena that occur during a limited period in organized structures. But the boundaries of this limited period are left undefined, and must consequently be supplied by the imagination of the reader. They may include even the phænomena of death, for anything that the definition shows to the contrary. Mr. Lawrence's

* Communicated by the Author.

$\uparrow$ Recherches Physiologiques.

† Traité de Physiologie. definition 
definition is very brief. It is as follows: "Life is the active state of the animal structure*." This evidently excludes the torpid state. It excludes also vegetables, which it might indeed be made to embrace by the insertion of a single word. But if life may exist even in a state of rest, surely it cannot be well defined, merely by calling it a state of action.

A writer, who regards the above definitions as savouring too much of materialism, not to say atheism, gives us another definition,-the briefest of all: "Life is inherent activity + " This, it must be acknowledged, is scanty enough: but it is abundantly comprehensive; for it includes everything of which inherent activity can be predicated, be it mind, or be it matter. Yet this is going a great deal further than its author intended, seeing that it is an approach to the materialism of which he accuses others. There is an inherent activity in the movements of the Aurora borealis, the merry dancers of the North; but it is not life. There is an inherent activity in the vivid coruscations that dart across the sky, and illuminate the loaded atmosphere in a night of electrical tempest; but it is not life. There is an inherent activity in the cause that occasions the eruption of a burning mountain,-- that subterraneous artillery which melts the solid and primæval rocks, and upheaves them in floods of liquid lava ; but it is not life. Yet according to the definition we ought to say that it is life, because it is a manifestation of inherent activity. Now inherent activity is not even an entity, but an abstraction. It is not life, but a property of life. It is not peculiar to living bodies, but is possessed by many bodies that are thought to be inert. What are chemical, magnetical, and electrical repulsions and attractions, if they are not examples of inherent activity?

It would be presumption in me to attempt to do that which the above distinguished physiologists, or their more orthodox criticizers, have failed to do; namely, to exhihit a correct idea of life, by the selection of a single trait. But as their

* Lawrence On Physiology. 52.

+ Rernarks on Scepticism; by the Rev. T. Rennel. 1819.

[Mr. Rennel's work, not long ago, made some noise in the world. We believe, however, that this writer is destined to find his place in the temple of fame among those worthies who in former times insinuated charges of atheism against Newton and Locke; and we trust that the same freedom will be claimed for the philosophy of mind, which has of late been ably asserted, by Professor Sedgwick and others, for Geology and Zoology. Surely nothing can be less calculated to confirm the religious belief of mankind than attempts to persuade them that every discovery or new view in philosophy is hostile to religion. Can those be justly charged with irreligion who refuse to assign arbitrary limits to the power of the Deity, as to the properties which he may confer on matter?

We shall have to notice a recent instance of misrepresentation similar to that to which we here allude, in our next.-EDir.]

N.S. Vol. 10. No. 55. July 1831. 
failure seems to be attributable, chiefly, to an unnecessary effort at brevity,-brevis esse laboro, obscurus fo,-perhaps it might be worth our while to try the effect of a fuller enumeration of particulars. What we lose in point and neatness, we may gain in perspicuity; and upon this principle $I$ submit the definition that follows:-Life is that attribute or energy of organized structures which renders them susceptible to impressions, and enables them to discharge functions. It is real, or it is potential:- - real, if the energy is in operation; as in the case of an animal in motion, or of a plant protruding its buds and blossoms;-potential, if the energy is dormant, as in the case of an egg not hatched; or of a seed not sown; or, as in the case of the hybernation, whether of plants or animals. Life originates in precedent life, and terminates in subsequent death, which is an extinction of all vital functions, and of all possibility of vital functions.-Taking this definition, with its illustration, as our text, we proceed to remark that life in the exhibition of its phænomena always presupposes the existence of certain peculiar conditions, previous, concomitant, or consequent, without which it has never been known to manifest itself, and of which the most essential are the following,-parentage, organization, aliment, aëration, temperature, death.

Parentage.-There was a time in which philosophers believed in what was called the doctrine of equivocal generation - that is generation springing from a fortuitous concourse of atoms having an appetency to combine themselves into living forms. This doctrine was taught and maintained by the most celebrated philosophers of antiquity. Plants were regarded by Diogenes as being generated from a mixture of earth and putrid water; the water acting upon the earth, and moulding it into form*. Plants whose seeds are not apparent were regarded by Theophrastus as being propagated by spontaneous generation, because some tribes of animals were thought to be so propagated + ; and parasitical plants were regarded as springing from some corrupted matter generated on the tree producing them $\neq$. The poets of antiquity had the same fictions. Ovid replenishes his post-diluvian world with animals that sprang up out of the earth sponte sua, excited by heat and moisture $\S$. The philosophy of the dark ages was not tikely to correct the errors of antiquity; and when a better philosophy was introduced, at the time of the revival of learning, it could not be expected to correct them all at once. Even Bacon, the great reformer of philosophical methods, still gave his sanction to the doctrine of equivocal generation,

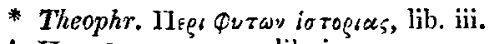

$+\Pi_{\varepsilon \rho} \varphi_{\nu \tau \omega \nu} a_{1 \tau} \omega_{\omega \nu}$, lib. $i$.

$\$$ Ibid. lib. v.

$\S$ Metamorph. lib. i. 
as may be seen by perusing his Sylva Sylvarum. The mosses that grow on trees he regards as being nothing more than a sort of excretion which the tree cannot assimilate; and the misletoe he represents as being produced, not from seed, but merely from superabundance of nourishment.

Yet the truth of the doctrine began to be at last suspected, and suljected to the test of observation and experiment. It was a scrutiny which it could not stand, and beneath which it fell refuted. The credit of the retutation is due partly to Harvey, who contended that all animals spring from an egg deposited by a parent,-_omne animal ex ovo; and partly to Francisco Redi, an Italian philosopher and physician, whose experiments are well known, together with their result; namely, that there is no such thing as a generation of insects from putrefaction. Similar investigations were applied to the vegetable kingdom by Malpighi and others, with similar results, demonstrating that all plants spring from seed, the produce of a parent, - omnis planta e semine. In short the doctrine of equivocal generation came into universal disrepute; and the stories of showers of frogs that fell from the clouds, and of armies of insects engendered by the east wind, and wafted on its wings, together with the marvellous account of a plane tree that sprang up spontaneously out of a brazen tripod, as related by Theophrastus, were no longer credited.

Such was the triumph of truth over error. Yet the very progress of the science that achieved it gave rise to new doubts. In the advance of microscopical discovery, a new world was laid open to the view of man, namely, that of the animalcula infisoria and spermatica. The most successful of the earlier operators in this department were Leuwenhoeck, Needham, and Swammerdam. Leuwenhoeck estimated the size of the smallest of these minute animalcules, and found that upwards of 1,000,000 of them might be contained in a space not larger than that occupied by a grain of coarse sand*. Concerning their origin every philosopher had his own opinion. Some regarded them as being generated by parents of the species, rather from analogy, than from any direct proof, which, in objects so minute, it must be next to impossible to obtain. Buffon regarded them as being, not the product of generation, not germs or embryos, not either animals or vegetables, but merely organic and moving particles proper to compose a living being.-If this were really the case, the species or varieties of animalcula would be interminable, as there would be no end to new combinations of organic particles, and no certainty of finding tomorrow the species you may have met

* Phil. Trans. Abridged ; vol, ii. 377 . and vol. iii. 203. 
with today. But the contrary of all this is the fact. The species are not interminable, but circumscribed, and in some of them the mode of propagation has been actually ascertained. But animalcules have been found in infusions that have been boiled, roasted, and even subjecterl to the heat of a blowpipe ; and this has been regarded as a proof that they have not proceeded from anything possessing life. Yet some species of seeds will survive even the action of boiling, and their germs, as we may suppose, are not less vivacious than themselves; and if the infusions in question were deprived of everything vital, whence came the animalcules?-They must have come from without. They must have penetrated the containing vessels; - a fact which cannot be admitted without due evidence. Fray affirms that he found animalcules in mineral mixtures *; and the same doctrine has been again advanced by Brownt, who finds them in rock, glass, ashes, soot, when ground to an impalpable powder and mixed with a little water. But as this question may be said to be yet sub judice, we will adopt the proposition of Cuvier, and say with him, "La vie ne nait que de la vie $\neq, "-L i f e$ originates only in life.

This proposition has been a good deal carped at, unfairly, as we think, by Barclay $\S$, who disapproves of the doctrine which it contains altogether, and asks whether the first individual, or the first pair of any species, could have come into existence in this manner?-The answer is ready. Cuvier's object was not that of tracing phænomena to their first causes, which may lie concealed for ever from human view, but merely to such causes as fall within the sphere of human observation, and are cognizable by human means. This is philosophy; this is physiology. 'The study of a first cause is religion; and our knowledge of it is derived, chiefly, from revelation. We do not say that it must necessarily be excluded from physiological research; but if the individual inquirer chooses to ex. clude it for the purpose of keeping separate two subjects that are perfectly distinct, he is not therefore to be regarded as an atheist. What light has Dr. Ure thrown on geology by his boasted introduction of the agency of a first cause? - But, says Barclay, what are we to make of the animalcula infusoria? It has not been proved that they are the product of generation;

- Essai sur l'Origine des Corps organisís : Barclay.

+ [Justice to Mr. Brown requires from us a remark on this point. It will be found, on perusing that gentleman's papers on Active Molecules (Phil. Mag. and Annals, N. S., vol. iv. p. 161, vi. p. 161), that he nowhere ascribes animal life to them, as the cause of their motion, and consequently ought not to be stated as regarding them to be animalcula. In the latter paper, indeed, he has expressly denied that he considers the active molecules to be animated.--Evir.]

\pm Leçons d'Anet. Compar. : Barclay. fon Life and Organization. 318. 
and yet they are evidently endowed with life.-To this we will reply by the following question. Has it been proved that they are not the product of generation?-If the higher orders of animals, the animals with which we are best acquainted, are evidently the product of generation, ought we not to conclude from analogy, that other and inferior orders of animals, with which we are less acquainted, are the product of generation also? or at the least of some process analogous to it, and leading to a similar issue. On this ground we rest satisfied of the legitimacy of Cuvier's conclusion.

Organization.-A very general and very good division of the bodies existing in nature, is that by which they are distributed into two primary classes of organized and unorganized productions. If we suppose a gradation by which all natural bodies are placed according to their rank in the scale of being, the unorganized substances will be found at the bottom. They exhibit no indications of life, no susceptibility to impressions, no sympathy of parts, no functions. Still they possess a definite number of properties by which they are readily characterized. Their properties are physical or chemical ;-gravity, elasticity, mobility, affinities, attractions, repulsions. They display also a gradation among themselves. Some of them are found merely in shapeless lumps that accident seemis to have thrown together, and that accident may again disperse; - masses of rock, masses of minerals. Others are found to present themselves in regular and symmetrical forms, whether individually or in the aggregate;-crystals, masses of crystals. If we regard the fabric of the earth which we inhabit, we find that it is moulded into an immense and globular mass; but it is destitute of all organization, as are the fluids with which it is watered, and the gases with which it is surrounded. The same remark may be extended, as we presume, to the heavenly bodies also;-the sun, the stars, the planets, and their satellites.

Organized bodies form the second class. They stand higher in the scale of being, and are endowed with nobler properties. They are the sole receptacles of life, which has never yet displayed itself except in such fabrics. 'They consist, in their living state, partly of solids, and partly of fluids in motion. The fluids are the materials out of which the solids have been formed,-chyle, blood,-sap, proper juice; or they are secretions, or exhalations, or excrements coming from the solids; -bile, urine, perspirable matter,-gum, nectar, perspirable matter. In the aggregate they form a fabric which is composed of a definite system of individual fabrics or organs, which constitute in their assemblage an individual whole :-a 
plant, an animal. An organ is a fabric adapted by its structure to the performance of a function; - a hand, a foot, a leaf, -prehension, progression, aëration. Bichât has remarked that the organs destined to the higher functions of the higher orders of animals-the organs by which they communicate with the external world-are more symmetrical in their form than other organs, and miany of them double, as the eyes, the ears, the hands, the feet; or divisible into two corresponding hatves, with a manifest medial line,-as the brain, the tongue. The higher the function the greater the symmetry of the organ *. We may extend this remark to vegetables also. It will not be found to apply so generally, nor in the same degree; but it is easy to discern traces of the fact. The leaves and petals are among the most important of all vegetable organs, and they show this peculiarity very conspicuously. They are divisible into an anterior and posterior surface; and into a right and left side separated by the intervention of a midrib. The interior organs of the flower may be regarded as divisible into two equal and similar halves; the spongiolæ of the radicles may be regarded in the same light; and perhaps the beautifully twisted form of the spiral threads should be regarded also as an example of the symmetry in question. An assemblage of several organs all concurring to the production of a single result constitutes an apparatus,- - the visual apparatus, the digestive apparatus, the lacteal apparatus. An assemblage of organs possessing the same or a similar structure constitutes a system,--the vascular system, the osseous system, the nervous system. The immediate constituents of organs are tissues, the cellular tissue, or the fibrous tissue.

Of all living bodies whether plants or animals, the principal mass is composed of the cellular tissue. It enters into the composition of almost every organ, and binds and cements together the fibres that pervade it. Particularly, it forms the principal mass of succulent plants, and a notable portion of many parts of woody plants. It abounds in succulent fruits, and in the lobes of all seeds. It consists of clusters of little cells or vesicles containing an inclosed fluid, which Grew compared in their aggregate aspect to the bubbles formed upon the surface of liquors in a state of fermentation.-The foetus seems a homogeneous mass of cellular tissue filled with a gelatinous fluid. As the organs begin to show themselves this mass becomes more condensed. As the bulk of the organs increases, the proportional bulk of the tissue diminishes. It is the receptacle of lymph and of fat, and is at all periods of

* Recherches Physiologiques, par Xiv. Bichât. 8. 
life that on which depends the plumpness or embonpoint of the individual*.

Of all living bodies whether plants or animals, a notable portion is composed of the fibrous tissue. The fibres are arranged in groups or bundles passing longitudinally throughout the whole extent of the organ, as in the slip of Aspidium Filix-mas; or in the nerves, muscles, and tendons of the animal fabric. When viewed superficially, a group appears to be merely an individual fibre; but when inspected minutely, and under the microscope, it proves to be made up of fibres smaller and minuter still, firmly cemented together and forming in the aggregate a strong and elastic thread, but capable of being split into a number of component fibriles, till at last they become so fine that you can divide them no longer. But in some organs they are arranged in thin plates or laminæ, as in the net-work of the cortical and woody layers of plants; and in the composition of the sclerotica and periosteum of animals $f$.

Every organ is invested, and if admitting it, lined, with an envelope of fibrous or of cellular tissue; and every living individual is enveloped with a covering of bark or of skin, or at the least with a fine epidermis. If the tissues are themselves examined with a view to ascertain the elements of their own composition, they will be found to consist of fine films or fibriles, which seem to be themselves composed of multitudes of minute and gelatinous globules closely compacted together, and distinguishable only by the microscope. Their diameter is represented as not exceeding the $\frac{1}{300} \overline{0}^{\text {th }}$ part of an inch; but their existence is by somedoubted. Beyond this, the analysis of the dissector cannot go. Here his anatomy ends. If he proceeds to chemical analysis, he will find that the proximate principles of the animal solids are chiefly albumen, fibrin, gelatin; the remote principles being azote, oxygen, hydrogen, carbon, with the azote predominating $f$.

Of the vegetable solids he will find that the proximate principles are chiefly albumen, fibrin, gluten, sugar, gum, extract; the remote principles being carbon, hydrogen, oxygen, with the carbon predominating $\$$. When the proximate principles of animals, albumen, fibrin, gelatin, are converted artificially from a fluid to a solid state, as by the action of heat or of other chemical agents, multitudes of ninute globules, similar to those of the blood, are said to be developed in the

* Anatomie Ginirule, par M. Bichât. 98.

+ Anat. Générale, torn. ii. 251.

$\S$ Davy's Agricultural Lectures.

$\ddagger$ Magendic, by Milligan. 10.

mass. 
mass*. It is a presumption in favour of the globulous structure of ultimate, living tissue.

Do the vital powers reside in the fluids, or in the solids, or in both? Some physiologists would confine them to the solids. But if the solids originate in the fluids, how can the fluids themselves be destitute of vital powers? They would thus present the singular anomaly of communicating that which they do not possess. Mr. J. Hunter believed in the vitality of fluids; or, at the least, in the vitality of the blood. But Blumenbach can see no ground for adopting this opinion. If you grant vitality to the blood because it is the material out of which the living solids are formed, as well, says he, may you grant it to water because the Nympheæ and many other remarkable plants are nourished by it $\dagger$. We do not think that the case is fairly put. Blood is an elaborated fluid fit for immediate assimilation, and the vegetable fluid corresponding to it is not water, but proper juice.

Bichât is also of opinion that fluids do not possess vitality, because they are incapable of contraction and of sensibility. Fluids he regards as merely passive, and solids only as active $\ddagger$. But fluids are stimulants, or exciters at least, and thus they act upon solids. The blood stimulates the heart to action, and ardent spirits stimulate the brain. After all, Bichât admits that the fluids begin to acquire animalization and vital properties in the course of their elaboration in the system. The chyle is more animalized than the alimentary mass; the blood than the chyle. This is granting enough to sanction the vitality of some fluids; and the vitality of all fluids is not contended for. But why should we doubt the possibility of endowing a fluid with vitality; or in what respect is it more easy to conceive a solid endowed with it than a fluid? The rudiments of the solids exist already in the fluids, that is, in the fluids elaborated for nutrition; so that the former can be nothing else than a more compact aggregation of the minute and semi-organized globules of thelatter, effected by the agency of the living powers of the plant or animal in some specific and determinate manner. The fluids of the human body are represented by Bichat as being to the solids in the ratio of 9 to 1 ; and the fluids of vegetables as being to the solids in a greater ratio still. Many of them contain globules of a regular figure and magnitude, particularly the blood, lymph, and chyle; and the spermatic fluid contains millions of animalcules. The fluids yield by chemical analysis the same principles as the solids $\oint$.

[To be continued.]

* Edwards De l'Infuence des Agens physiques sur la Vie.

+ Blumenbach's Physiology, by Elliotson. 21 .

I Anat. Génér. 24.

$\oint$ Magendie, by Milligan. 14. 